\title{
Evolution and Diffusion of the Michigan State University Tradition of Organizational Communication Network Research
}

\author{
Alex M. Susskind* \\ Cornell University \\ Donald F. Schwartz \\ Cornell University \\ William D. Richards \\ Simon Fraser University \\ J. David Johnson \\ University of Kentucky
}

Final versions published in Communication Studies (2005), 56(4), 397-418

\section{$\underline{\text { Author Note }}$}

Alex M. Susskind (Ph.D.) is Associate Professor at the School of Hotel Administration, Cornell University, New York.

Donald F. Schwartz (Ph.D.) is Professor Emeritus at the Department of Communication, Cornell University, New York.

William D. Richards (Ph.D.) is a Professor at the School of Communication, Simon Fraser University, Burnaby, Canada. 
J. David Johnson (Ph.D.) is a Professor and Dean at the College of Communications and Information Studies, University of Kentucky, Lexington.

This article is based on a paper presented at the XXIlth annual conference of the

International Network for Social Network Analysis, New Orleans, LA, USA, February 12, 2002.

*Correspondence to: Alex M. Susskind, School of Hotel Administration, Cornell

University, Ithaca, NY 14853, U.S.A. Tel: (607) 255-8839; Email: ams76@ cornell.edu 


\begin{abstract}
This article documents the 30-year history of communication network research at Michigan State University (M.S.U.), providing a case study of the evolution and diffusion of an academic innovation. Three past and continuing issues for network scholars are identified: a lack of professional reward for developing user-friendly computer programs, unresolved methodological problems, and a need for better theoretical and conceptual frameworks. The narrative also illustrates the difficulty communication as a discipline has in impacting broader intellectual traditions. The story begins with the first doctoral dissertation (Schwartz, 1968) and the first network analysis software program in 1970 (Richards' Negopy), continuing to the last dissertation (Susskind, 1996), and ending in 1998 when J. David Johnson left the M.S.U. faculty. Other major players in the M.S.U. network tradition included David K. Berio, Eugene Jacobson, Everett M. Rogers, Vincent Farace, Peter Monge, and Erwin Bettinghaus. Ironically, Schwartz and Susskind met in 1998 while Schwartz was preparing to retire from Cornell University and Susskind was starting as an Assistant Professor in a different department, thus providing closure to the M.S.U. network.
\end{abstract}

Keywords: Network Analysis; Communication Networks; History of Communication Network Analysis; History of Communication; Evolution of Research Tradition 
Evolution and Diffusion of the Michigan State University Tradition of Organizational Communication Network Research

Recent years have seen a resurgence of interest in network analysis in the social sciences (Biggart \& Delbridge, 2004; Monge \& Contractor, 2003; Pescosolido \& Rubin, 2000; Seary \& Richards, 2003; Seary, Richards, McKeown-Eyssen, \& Baines, 2005) and even the natural sciences (Barabasi, 2003; Buchanan, 2002; Newman, 2003), owing in part to the development of such heuristic concepts as social capital (Coleman, 1988; Putnam, 2000; Seibert, Kraimer, \& Liden, 2001) and structural holes (Burt, 1992,2000; Finlay \& Coverdill, 2000; Taylor \& Doerful, 2003). Interestingly, as this essay details, communication as a discipline had considerable "first mover" advantage in developing network research, but was never able to capitalize on it for reasons partially revealed in this history of network analysis research at Michigan State University (M.S.U.).

From 1968 to 1998 a series of Ph.D. dissertation studies in the M.S.U. Department of Communication investigated communication networks in organizations. The series began with the joint interests of a graduate student, Donald F. Schwartz, and an adjunct communication graduate faculty member, Eugene Jacobson who was an organizational behavior scholar in psychology. Communication network research at M.S.U. was nurtured over the years primarily by Jacobson and three Communication faculty members: Everett M. Rogers, who was on the M.S.U. faculty from 1964 to 1973 and served as a member of Schwartz's advisory committee; R. Vincent Farace, a faculty member from 1965 to 1987 who was joined on the faculty by Peter Monge, his former student, from the late 1970s through the early 1980s; and J. David Johnson, who completed his M.S.U. Ph.D. in 1978 and joined the M.S.U. Communication faculty in 1988, leaving in 1998. Johnson was a member of Alex Susskind's doctoral committee. Susskind's 1996 
dissertation was the last in the M.S.U. series. After Johnson left M.S.U. in 1998, no one on the communication faculty taught network analysis.

Because the early studies were not immediately published, the M.S.U. network research in the late 1960 s and early 1970 s can be characterized as an "invisible college" (Rogers \& Agarwala-Rogers, 1976). So-called invisible colleges form around a revolutionary paradigm where scholars exchange unpublished papers and "commune with each other at small select conferences and seminars" (Price, 1970, cited by Rogers \& Agarwala-Rogers, 1976). Most of the “communing" about communication network analysis was within the M.S.U. Department of Communication among faculty and graduate students, but also included M.S.U. Ph.D. alumni, largely at annual International Communication Association (I.C.A.) conferences. Schwartz presented the first conference paper at I.C.A. in 1969. It wasn't until 1972 with establishment of the I.C.A. organizational communication audit project that communication network analysis began to diffuse beyond M.S.U. and the invisible college began to wane. It "went public" with the first published journal article in 1974 by Farace and MacDonald.

This article is the story of the M.S.U. communication network analysis tradition. Our purpose is to document the personal and intellectual history of that work as an illustration of the evolution of an academic innovation in a young discipline. Our narrative illuminates three past and continuing issues for network scholars generally, but it also reveals how a group of academic entrepreneurs failed to confront these problems making it difficult for them to impact larger, more mature academic disciplines. The first issue is a lack of professional reward for developing user-friendly computer programs for network analysis. The innovative work of Bill Richards at M.S.U. yielding one of the first software programs was a fortunate effort that few others attempted early on. Over the years others have accepted the challenge and low professional 
reward ratio of software development, but in a point-and-click era user-friendliness remains an issue. Second are unresolved methodological problems, such as the reliability and validity of network data and the application of statistics to relational data. As a discipline communication has never developed the specialization of a field like physics where experimentalists and theoreticians serve as a useful counterpoint to each other, with experimentalists constructing ever more sophisticated tools to measure and assess theoretical ideas. Finally, communication has depended on other disciplines for the theoretical and conceptual frameworks that guide our research. Given our relative size and position in the academic firmament, it is only at the early stages of inquiry that we might have the best opportunity to shape broader intellectual traditions.

\section{Prehistory}

The M.S.U. network analysis story begins at the University of Michigan in 1950. The network concepts and methodology adopted for the early M.S.U. network studies were developed as part of an organizational study conducted for the Office of Naval Research (O.N.R.) by Eugene Jacobson and Stanley Seashore at the U.M. Institute for Social Research. Jacobson and Seashore's conceptual framework for the network portion of the O.N.R. study was clearly communication based: “'Organization structure' can be conceptualized in terms of communication events which connect pairs of individuals, and thus establish patterns of contact among individuals and among groups" (1951, p. 33). Respondents filled out a socio-metric questionnaire listing the names of others in the organization with whom they worked most closely and indicating the frequency and importance of each relationship, a basic approach that has not really changed through the decades. The algorithm for analysis of the network data was developed by Robert S. Weiss, a Ph.D. candidate in sociology, based on graph theory concepts of 
an articulation point and a bridge. ${ }^{1}$ The communication portion of the O.N.R. project yielded two papers: Jacobson and Seashore (1951), and Weiss and Jacobson (1955).

\section{The Early Network Studies at M.S.U.}

Eugene Jacobson moved to Michigan State University in 1955 as an Associate Professor of Psychology. Along with Milton Rokeach, John Useem, and Archie Haller, he was an “informal" adjunct member of the graduate faculty in the new ${ }^{2}$ Department of Communication (E. Bettinghaus, personal communication, January 22, 2001). It was not until 1966 that he became re-involved in an investigation using network analysis.

Donald F. Schwartz came to M.S.U. as a doctoral student in the fall of 1964. His interest in organizational behavior and communication stemmed from undergraduate experiences in student leadership positions and administrative experience as assistant director and acting director of university relations at North Dakota State University. Of particular interest was the effect of the web of inter-personal influences within which organizational administrators operate. Schwartz learned of Jacobson's research on organizational networks while discussing potential advisory committee members with David K. Berio, chairman of the M.S.U. Department of Communication. Reading Jacobson's network analysis articles led Schwartz to ask him to be on his committee, joining Hideya Kumata, chair, Everett M. Rogers, and Gerald R. Miller.

Schwartz's dissertation proposal was approved by his advisory committee early in $1967 .{ }^{3}$ He pretested his data collection instruments among faculty of the M.S.U. Department of Communication. The data for the main study was collected from M.S.U. College of Education faculty and academic administrators housed in the main College building. 
Schwartz returned to N.D.S.U. in summer 1967 to complete a sabbatical leave obligation. He completed data analysis and dissertation writing the following summer. No computer programs existed for analyzing the network data using the Weiss algorithm. The analysis was very labor intensive, requiring recopying the matrix of contacts by hand each time a tentatively identified liaison person was removed from a sub-matrix.

While Kumata chaired Schwartz's advisory committee, he deferred to Jacobson for advice on the study itself; in function, Jacobson was the dissertation adviser. Schwartz successfully defended his dissertation at M.S.U. in September 1968.

The first public sharing of the M.S.U. network work was the paper based on his dissertation that Schwartz presented at the 1969 national conference of the International Communication Association (then named the National Society for the Study of Communication). The paper was published in the E.R.I.C. Speech Communication module in April 1975 and reprinted in Porter and Roberts' (1977) reader. At the 1970 I.C.A. conference, Schwartz fielded questions about network analysis from several

M. S.U. graduate students and held an informal "seminar" with five students in the hotel bar one afternoon. The invisible college was beginning to perk at M.S.U.

At N.D.S.U. Schwartz initiated a new course in organizational communication in 1968, among the first under-graduate organizational communication instruction in the nation. Except for small-scale network analysis exercises by students in his classes at N.D.S.U. and later at Cornell University, he undertook no other network studies. In 1969 he was named chairman of the N.D.S.U. Division of Social and Behavioral Sciences and began an 18-year career in academic administration and teaching at N.D.S.U. and Cornell. Although carrying heavy teaching and administrative obligations at N.D.S.U., he continued work on the original study 
data and in 1975, with Jacobson, submitted a manuscript to Organizational Behavior and Human

Performance. ${ }^{4}$ It was published in 1977 and later was reprinted in Katz, Kahn and Adams' (1980) reader.

By 1977 when the O.B.H.P. article was published and nine years after Schwartz defended his dissertation, the invisible college was much less invisible. One reason was that Professor Farace and his M.S.U. students began publishing their communication network research (Farace \& MacDonald, 1974). Another reason was the I.C.A. organizational communication audit project started in 1972. Schwartz and MacDonald were original members of the project committee and urged using network analysis as an audit methodology. MacDonald's network analysis dissertation at M.S.U. (MacDonald, 1970) was patterned on Schwartz's study. For the 25 or so I.C.A. members involved in the audit project, Schwartz and MacDonald's presentations were their first exposure to communication network analysis and several adopted it for their own research.

\section{Meanwhile Back at M.S.U.}

Two major research projects initiated in the Department of Communication in 1968 used network research as one of the analytic tools. David K. Berio was the principal investigator for both projects and Eugene Jacobson was a key resource person. One project was a departmental contract with the national Office of Civil Defense (O.C.D.). The other was a consulting contract Berio had with the Chase Manhattan Bank. Berio assembled teams for both projects that included R. Vincent Farace as principal coinvestigator. Farace joined the Communication Department in 1965 after completing his Ph.D. in Communication at the University of Iowa. Farace's initial research centered on mass communication and national development, but his 
involvement in the O.C.D. and Chase Manhattan projects moved his focus toward the study of communication in organizations. While he never taught a separate graduate seminar in communication network analysis, he taught the M.S.U. graduate seminar in organizational communication (originally taught by Berio) and included network analysis as part of that course. At the time he left the department in 1987, Farace had supervised more Ph.D. dissertations that used network analysis than any other department faculty member. With Peter Monge and Hamish Russell, two of his graduate students, he published the first graduate-level organizational communication text in the field, Communicating and Organizing (1977).

Several graduate students were involved on one or both teams for the O.C.D. and Chase Manhattan projects, but four who later used and published network research were Donald MacDonald, Peter Monge, Hamish Russell, and James Danowski. MacDonald's dissertation came from the O.C.D. project data and used both the network role concepts and the Weiss algorithm from the earlier work of Schwartz, Jacobson, and Seashore. Like these four pioneers, MacDonald did not publish another large-scale network study before his untimely death in a traffic accident.

Although not in conjunction with the O.C.D. or Chase Manhattan projects, Everett M. Rogers supervised four M.S.U. dissertations involving network analysis between 1970 and 1973. Rogers earned a Ph.D. in sociology at Iowa State University in 1957 and came to M.S.U. in the fall of 1964 from a faculty position at Ohio State University. He had already published the first edition of The Diffusion of Innovations (1962). As a diffusion scholar he was no stranger to network analysis, although diffusion research to that point typically only mapped the pattern of opinion leader influence in a social system. He included instruction about network analysis in his diffusion courses and seminars. He also initiated the first M.S.U. under-graduate organizational 
communication course in 1966, perhaps the first in the nation, and discussed network analysis in that course. After Rogers left M.S.U. in 1973, he and Larry Kincaid, one of his former graduate students, published the first book on communication network analysis (1981).

\section{Richards and NEGOPY: Software to the Rescue}

In the conclusion to his dissertation, Schwartz (1968, p.164) observed: "One development which would greatly facilitate studies of this type would be a computer program designed to treat communimetric data for identification and classification of topological properties such as the liaison role." Because no computer programs existed for network analysis, network data had to be entered and analyzed manually. The process took huge amounts of time and was prone to simple copying errors. It took an M.S.U. under-graduate to offer a way out of this problem.

In 1970 Bill Richards was an M.S.U. under-graduate who had sampled courses in communication along with a mix of math, psychology, sociology, statistics, and computer science. That fall, he enrolled in Jacobson's under-graduate social psychology course and in Farace's large under-graduate course on organizational communication (which Farace had inherited from Rogers). Richards was writing simple computer programs for faculty and graduate students to do means, standard deviations, cross-tabulation, and index construction for Likert scales. Farace and graduate students MacDonald, Monge, and Russell worked on network data from the Office of Civil Defense project using a large matrix on one wall and another on the floor (using 174- inch graph paper, the matrices for some 300 people were about six feet square). They worked on it every evening, week after week, two standing at the wall reading numbers from one matrix and two on the floor, writing on the other one. Curious about the project, Richards asked one evening what they were doing. "This is network analysis," one of them said. 
Richards asked, "Why don't you have a computer do that?" He recalls that they laughed at his suggestion.

Shortly after that evening, Richards asked Jacobson for ideas for a term paper. Jacobson suggested he read "the paper I did with Stanley Seashore in 1951." Reading the article - the same one Schwartz read before asking Jacobson to be on his Ph.D. committee, Richards was surprised to learn about the matrix manipulation method (Weiss' algorithm) the authors had used to move the non-zero entries ("l"s representing communication contact) closer to the diagonal. He guessed that was what Farace and his team were doing with their big matrices. He tells this story about what happened next:

I was in the library and I thought "I bet I could make a computer do that." I figured that if two people were in the same clique, they likely talked to the same people. If I take the mean of the ID numbers of the people they have links with, the means should be similar. People in different cliques would have different means because they talk to different people."

Richards tried this idea with dummy data, finding that if he rank-ordered the means and used the ranking to permute the rows and columns of the matrix, the non-zero entries were a bit closer to the diagonal but not close enough. Next he tried a new set of means, using the rank positions instead of the original ID numbers. He ranked the new means and made a new adjacency matrix with that ordering of rows and columns. He found after two or three more iterations that the "l"s coalesced along on the diagonal and it was quite easy to visually identify the cliques as clusters of "l"s. Richards wrote his term paper for Jacobson's class about the procedure.

About the same time, Richards learned of Berio's Chase Manhattan Bank study, which included communication contact data for 960 people. He calculated that with $1 / 4$-inch graph 
paper they would be working with a 20 -foot square matrix that would take over a year to analyze and they would make a lot of unrealized transcribing errors because there was just too much data to record and track accurately. Meanwhile Richards had submitted his paper for Jacobson's course to the 1971 International Communication Association conference, not expecting acceptance because he was "only an undergraduate." The paper was accepted, so he asked department chair Berio for travel money to the conference in Phoenix. Berio said there wasn't enough money for all of the professors, so he couldn't support an under-graduate. "But," he said, “please give me a copy of your paper.” A few days later, Richards was called to Berio's office. Berio held up the paper and asked, "Can you do this?" "I think I can." "Good. Get to work. We will pay you $\$ 5$ per hour. Oh, by the way, we found travel money for you to go to the conference."

That spring Richards was accepted for graduate study in communication at Stanford University where Rogers was on sabbatical at the time. At the I.C.A. conference, Rogers suggested that Richards fly to Santa Barbara after the conference, drive up the coast with him, stay at his home and he would introduce him to faculty in the Institute for Communication Research. At lunch on the drive up the coast, the conversation was about networks. Richards asserted that network analysis would be a good method for studying the diffusion of innovations because it would be possible to examine the whole network rather than just the two-step link from the original source to the opinion leader to followers; i.e., with a systems theory perspective, one could analyze the communication network of the whole system, not just the parts removed from the overall context of connections. Rogers agreed and indicated he wanted to explore where network analysis might be applied. 
Richards continued work on his computer program at M.S.U. for the summers of 1971 and 1972, producing the first version of the program that he named Negopy - a contraction of “negative entropy" meaning "non-random structure." There were two main stages to the procedure that Richards applied to the Chase Manhattan data. The first stage just did the reordering of the rows and columns on the basis of the means. To see how the process was converging, it was necessary to print matrices that were so large they had to be printed in strips and then taped together on the wall. But this wasn't good enough for the Chase Manhattan data because the matrices were still too big. So Richards began developing the second part of the program that finds the cliques, liaisons, and isolates (for technical details see Rice \& Richards, 1985; Richards \& Rice, 1981).

In 1975 the first "complete" version of Negopy was ready for distribution to other researchers. It required a C.D.C. mainframe computer and handled networks with up to 4096 nodes and 64,000 links. Other versions followed: 1982, an I.B.M. mainframe version; 1985, an improved version for I.B.M., C.D.C., and D.E.C. V.A.X. machines; 1987, the first P.C. version (networks with up to 1000 nodes); 1991, an improved P.C. version (3000 nodes); and 1997, a Windows version (32,000 nodes and 700,000 links). Today Negopy has been used in disciplines from agricultural journalism to urban planning, and by scholars and consultants in over 20 foreign countries.

\section{The Middle Years at M.S.U.: Farace to Johnson, 1973-1988}

In the mid-1960s to early 1970s, with Berio and Rogers acting as rainmakers, the M.S.U. Department of Communication was literally flooded with grant money. The substantive focus on communication network analysis was partly out of necessity because it appeared to be a unique 
and promising tool for dealing with the problems that were the focus of their grants: for Rogers, the communication networks facilitating the diffusion of innovations and for Berio the internal communication problems encountered in organizations.

Unbeknownst to J. David Johnson when he entered the M.S.U. graduate program in the fall of 1973, M.S.U.'s network analysis era was consolidating for its next stage. The first stage was ending because both Rogers and Berio had left and Richards was only an intermittent presence, having gone to Stanford. The consolidation took on a number of forms. First, there was a conscious effort to erase the invisible college and to spread the word in the discipline of communication about the M.S.U. network analysis studies. This led to Johnson's only research project on Farace's research team, resulting in a showcase panel at the 1974 I.C.A. conference describing normative data mined from a number of M.S.U. network analysis research projects (Farace \& Johnson, 1974). The second was a focus on popularizing pedagogical tools in the form of Farace research team member Michael Pacanowsky's simulation which served as the handbook of the Farace et al. (1977) influential book and which also was used as research tool for examining various organizational hypotheses in a laboratory setting. Third, was development of a data bank composed of archived data and a collection of literature on network analysis drawn from a wide array of disciplines (Farace \& Johnson, 1974).

Farace's 1973-74 network research team ${ }^{5}$ was composed of a number of individuals who formed a strong clique for many years thereafter, notably Jim Danowski, Rolf Wigand, and (although he was not formally on the team) George Barnett. Many on this team, as well as the M.S.U. faculty members, contributed articles for Richards and Barnett's book (1993) and continued to work with each other well into the 1990s. While several team members were later 
quite successful (some, such as Mike Cody, in other areas of communication), none secured any refereed publications resulting from the team's work.

Johnson finished his Ph.D. course work in 1976 and left M.S.U., to return on the faculty in 1988. During this period Peter Monge, Farace's former graduate student, rejoined Farace on the M.S.U. faculty. Monge, Farace, and their graduate students, most notably Eric Eisenberg and Kathy Miller (who later also joined the M.S.U. faculty), worked on a variety of research projects, but few resulted in exclusively network studies. Most often their published research related network analysis to climate, human resources, and social support concerns. Teri Albrecht, a communication graduate student at M.S.U. in the mid-1970s, became known for a focus on the relationship of network analysis to social support, particularly related to burnout among nurses. Albrecht joined the University of Washington faculty where she worked with Mac Parks (a 1976 M.S.U. communication Ph.D. with network interests) and influenced Eileen Berlin Ray, eventually joining the University of South Florida nursing faculty. Later Eisenberg and Monge, joined by Noshir Contractor at the University of Southern California, also included cultural themes in their work in the form of semantic network analysis (Monge \& Contractor, 2003).

While a fair amount of network research was conducted at M.S.U. in the 1970s, this activity—because of issues regarding the conduct of network analysis (described here later)—did not reach the level of productivity of the M.S.U. inter-personal communication scholars during the same period. In part because of conflict that developed between the two camps in the late 1970s and early 1980s, Monge and Farace left M.S.U. When Johnson returned to M.S.U. as Farace's replacement in 1988, he had a much broader view of network analysis, and the department had a much narrower view of communication research. 


\section{Johnsons Path from MS. U. Graduate Student to Faculty Member}

Johnson came to the Ph.D. program in the Department of Communication at M.S.U. in 1973 while still completing his master's degree in social science multi-disciplinary research. He had a two-fold mission: learn methods and techniques on which to build a career, and focus substantively on individual reactions to formal organizations. While successful on the first, the second goal was ultimately frustrated by a clear bias in the M.S.U. network tradition against examining formal organizational structure, in part as a way of legitimizing a focus on emergent networks.

Johnson's introduction to network analysis came with his first research assignment on Farace's research team. As a result of this work he reached three conclusions: (a) the Negopy computer program of that era had a number of weaknesses; (b) self-report data for constructing networks was very problematic (something Bernard \& Killworth, 1977, would dramatically demonstrate for communication as a discipline in a few years, inhibiting publication of such data for a decade); and (c) the descriptive data on which network analysis was based provided a very limited view of human relationships.

Johnson functioned as a Cassandra for these problems within Farace's research team, but was not able to convince Farace or his fellow graduate students of their importance. Because Johnson saw these problems as major concerns, he decided to pursue a broader conceptualization of relationships in a mass media setting with a different dissertation advisor, Erwin Bettinghaus (see Johnson, 1982, 1984, 1985). Eugene Jacobson, Schwartz's dissertation advisor eight years earlier, was also on his committee. This move enabled Johnson to be one of the first adopters of another technique, LISREL. It also gave him broader exposure to communication problems leading to a more eclectic research program but one with a common theme of how individuals 
establish communication structures to perform the tasks they view as important in their life (e.g., seeking information relating to health, working with others in organizations, adopting innovations).

In 1976 Johnson left M.S.U. to work as a media research analyst for the United States Information Agency. While there he developed an interest in international/intercultural communication and pursued that for the next decade. He also developed an interest in the area of information seeking, a topic he developed more completely after returning to the M.S.U. faculty (Johnson, 1996, 1997a). He saw that information seeking dovetailed well with antecedent factors which lead to the development of networks and individual action within them.

Upon receiving his Ph.D. in 1978, Johnson left U.S.I.A. to teach organizational communication in a relatively traditional speech communication program at the University of Wisconsin-Milwaukee ${ }^{6}$ (where Fred Jablin was beginning his career ${ }^{7}$ and from which, coincidentally, Don MacDonald had recently left for the University of Tulsa). Johnson re-visited his network analysis roots, working with graduate students in organizational communication seminars. Based primarily on the M.S.U. dissertations, he developed a conceptual paper with Liz Reynolds on liaison communication roles (Reynolds \& Johnson, 1982) that acted as a precursor to some of his later research (Johnson, 2004).

In 1982 Johnson moved to Arizona State University where he did not have a strong organizational colleague (and the quantitatively oriented students were drawn to the interpersonal/persuasion tradition), so it became a period more of consolidation of his existing research. Work on multivariate networks (Johnson, 1987) led him to two key conclusions: Negopy was not being broadly accepted in the discipline and if he wanted to continue publishing in the network research area, he would have to learn a different computer program; 
paradoxically, despite its many weaknesses, it was becoming more acceptable in the discipline to use self-report network data because of the introduction of organizational culture and the growing realization that what people thought about reality might have more significance than reality itself.

Johnson next took a position at SUNY-Buffalo in 1985, moving to a department that had an organizational communication focus (including Gerry Goldhaber, a Purdue Ph.D.) and a group of committed graduate students. There Johnson continued to broaden his work on defining communication structure, including a wider range of approaches (e.g., culture and gradients), which led to his 1993 book, Organizational Communication Structure. Most importantly for his later network analysis work, Johnson started to examine other computer programs for network analysis, particularly UCINET and Ron Burt's STRUCTURE. ${ }^{8}$ He chose to focus primarily on STRUCTURE because of its embeddedness in Burt's ideas relating to social contagion and structural holes, and continues to pursue it theoretically (Johnson, 2004). Collaborating with Rosanne Hartman, Johnson published what he considers his best network analysis work (Hartman \& Johnson, 1989, 1990).

\section{The Latter Years: Johnson Back at M.S.U., 1988-1998}

Johnson returned to M.S.U. in 1988 as a faculty member. Johnson's doctoral committee chair, Erwin Bettinghaus, was Dean and strongly believed the department needed a network analyst on the faculty (Bettinghaus, 2001). Much had changed since Johnson left in 1976. The department was considerably smaller: Graduate student enrollment had declined from over 50 to fewer than 20, a direct result of the virtual disappearance of sponsored research projects. While the reputation of the department was intact, M.S.U. was not as exciting a place as it had been in 
the 1960s and early 1970s when it was leading the quantitative revolution in the communication discipline (Rogers, 2001). By and large M.S.U. had won a position of unquestioned preeminence. This was especially the case for the inter-personal/persuasion program, which essentially had become the core of the graduate program.

The key to the success of the department had always been the core methods and theory sequence that socialized each new Ph.D. class. When at M.S.U. as a graduate student, Johnson was trained by sociologists Joe Woeful and Ed Fink who naturally were sympathetic to more macro and network analysis approaches to communication as reflected in their later work (see Richards \& Barnett, 1993). By 1988 when Johnson returned, inter-personal/persuasion scholars - in effect social psychologists dominated both the theory and the methods sequence. This created insurmountable problems for training network analysis oriented graduate students because they had to be de-programmed" to accept the fundamental assumptions of network analysis (e.g., people are not independent of each other, as assumed in classic A.N.O.V.A./ regression based research; the ties they have are the critical influence on their lives). Another problem for attracting graduate students to network analysis was that both of the other organizational communication faculty members, Alicia Marshall and Kathy Miller (both of whom had been trained by and associated with leading network analysis researchers Cynthia Stohl at Purdue and Monge while at M.S.U., respectively) were not making network analysis the direct focus of their work.

Early in the 1990s Johnson chaired a search committee that hired Jim Dearing and Vernon Miller. Miller represented the Purdue tradition embodied by his advisor Fred Jablin. He collaborated with Johnson on a number of projects. Johnson and Miller also shared graduate students, most notably Alex Susskind. Jim Dearing was one of Everett Rogers last graduate 
students at the University of Southern California and shared Rogers focus on innovation and the ability to get grants. While Dearing never pursued network analysis while at M.S.U., he was highly influential in the work of Marcy Meyer and Torn Kiyomiya, graduate students who were on Johnson's research team and completed network analysis related dissertations.

When Johnson became M.S.U. department chair in 1992, he tried to hire additional network analysts, especially those who could inject new approaches to computer programs from outside the discipline. Unfortunately, the need for this specialization was not shared fully by the other communication faculty at the time (see Mayhew, 1980, for a discussion of these issues) and Johnson also was not successful in attracting candidates. He did, however, introduce capstone courses on communication structure in the under-graduate (COM 440) and graduate (COM 915) organizational communication sequences. These courses were the only place network analysis lived on at M.S.U., reflecting the lasting influence of formal structure.

Johnson became involved in several cancer-related research projects at the behest of Dean Bettinghaus who was then a member of the National Cancer Advisory Board. A major, and perhaps final for M.S.U., research project related to network analysis was the Cancer Information Services Research Consortium (C.I.S.R.C.) funded by the National Cancer Institute. This $\$ 7,300,000$ project $^{9}$ harkened back to the scale of projects M.S.U. led in the 1960s. While the grant was cast as a network analysis project, mostly because of Bettinghaus' vision of it, it really was more of a traditional audit of organizations focusing on innovation processes. Network data, however, were gathered over 14 time points covering the four years M.S.U. subcontracted this project.

While the C.I.S.R.C. project did result in a number of publications (e.g., Chang \& Johnson, 2001; Johnson \& Chang, 2000; Johnson, LaFrance, Meyer, Speyer, \& Cox, 1998; 
Johnson, Meyer, Berkowitz, Ethington, \& Miller, 1997; Johnson et al., 1996; Johnson, Meyer, Woodworth, Ethington, \& Stengle, 1998; Meyer et al., 1997), it was not as rich as it could have been in focusing on the network analysis data. Members of the research team did look at issues surrounding gender proportions and network relationships (Ethington, Johnson, Marshall, Meyer, \& Chang, 1996) as part of a larger study and Marcy Meyer (1996) received an I.C.A. Redding Dissertation Award for her work relating the network data, in the form of weak ties, and innovation processes. Unfortunately her study was never published.

Many students on the C.I.S.R.C. research team were very disquieted by several fundamental network problems. They also observed, in the clear Darwinian view only graduate students can have, that they had to work a lot harder to realize the same publication yield as graduate students who focused on inter-personal communication, drawing on under-graduate student samples. While the C.I.S.R.C. project could have continued for another four years, the lack of career advancement of graduate students for work associated with it was a major factor in halting the project.

Fortunately, however, Alex M. Susskind, a student in the Ph.D. program who was funded through his assistantship with the School of Hospitality Business, saw the potential for network analysis as a result of taking Communication 915 from Johnson and because of the rich network research that was burgeoning in organizational behavior and management. Ironically, just as communication network analysis was dying at Michigan State, it was taking off in other disciplines. In this story of the network analysis era at M.S.U., Alex Susskind is the last carrier of the network analysis flag. ${ }^{10}$ 


\section{The Last Dissertation}

Susskind came to M.S.U. as an M.B.A. student in the spring of 1991 and started his Ph.D. in the Department of Communication in the fall of 1993. He had under-graduate degrees and work experience in the restaurant industry. While he was interested in an academic career when he arrived at M.S.U., he did not know that his interests in personnel and human relations, training, and development would eventually lead him to a program of study in organizational communication and ultimately network analysis. He took all of his elective M.B.A. courses in organizational behavior and human resources management. His interest in human relations grew out of his work experience in the food-service industry and as an under-graduate culinary instructor at Purdue. He was perplexed by how the restaurant industry was plagued with bad attitudes, high levels of work-related stress, job burn-out, and a high turnover rate. His first research experience and conference paper was his under-graduate thesis that examined organizational commitment, job satisfaction, and turnover of hospitality-based employees.

In the M.S.U. M.B.A. program, Susskind was a graduate teaching assistant for a required food service management course. The course instructor was working on a Ph.D. in the Department of Communication, examining leader-member relationships. Conversations with his supervisor led Susskind to the study of organizational communication in the Department of Communication. At the time four faculty members were teaching and researching topics that interested Susskind: Johnson (networks and organizational structure), Vernon D. Miller (interviewing, organization socialization, and role development), Alicia Marshall (health communication), and James Dearing (diffusion of innovations and program evaluation).

Because Susskind's funding did not come from the Department of Communication, he had more freedom to pursue his special interests. Johnson supported half the department graduate 
students on the C.I.S.R.C. grant, which drew some reluctantly into network-related research. Susskind was a unique node in Johnson's network of graduate students because he was the only one who voluntarily took up the study of networks and completed a network-based dissertation without any involvement in the C.I.S.R.C. project or use of the C.I.S.R.C. data.

In his first year, Susskind began conceptualizing a study of how training needs and organizational communication changed as a function of organizational downsizing. The primary impetus for his use of network analysis came from Johnson's organizational communication seminar where he was exposed to the network literature, including Johnson's organizational structure book and Burt's (1992) structural holes book, and to three network software programs: UCINET, Negopy, and STRUCTURE. Burt's concept of structural holes ultimately framed Susskind's dissertation research as he examined how changes in a hospitality organization's network following a downsizing influenced individual attitudes and perceptions. Network scholars outside communication also influenced Susskind's work. Most of these scholars were sociologists (Linton C. Freeman, Ron Burt, Nan Lin, David Krackhardt, and Herminia Ibarra, to name a few). Many of them were employed in traditional business schools and were using network analysis to study issues that were a staple in the management literature: leadership, team interaction, power, influence, and organizational change. The increasing appearance of network studies in the management literature signaled a softening of the resistance toward network analysis brought on by the growing availability of alternative software programs and a general desire for more multi-level, multi-method research in the field. In 1998 when the first study from Susskind's dissertation was published (Susskind, Miller, \& Johnson, 1998), network studies were already taking a regular place in the top management journals (cf. Ibarra, 1993, 1995; Krackhardt \& Porter, 1986; Labianca, Brass, \& Gray, 1998; Shah, 1998, 2000). 
To date, Susskind has produced two articles from his dissertation data (Susskind, 2005; Susskind et al., 1998), both of which are complementary to the network tradition in management. In the second, he connects turnover intentions to the flow of information across a network undergoing strong planned change (i.e., downsizing). Recently he completed a new network study examining geographically dispersed research teams (Susskind \& Odum, 2004).

In 1998, Susskind accepted a position at Cornell University's School of Hotel Administration, with a joint appointment in the Graduate Field of Communication. The same year, Schwartz retired from the Cornell Department of Communication and was appointed Professor Emeritus. Schwartz's replacement, Dean Krikorian, who was trained in network analysis by Dave Seibold at UC-Santa Barbara, came to Cornell from a visiting position at M.S.U. Krikorian left Cornell in 2003 to establish his own consulting business, leaving Susskind to continue the network research initiative at Cornell University. ${ }^{11}$

The network tradition at M.S.U. is gone for now. Since Johnson's departure in 1998 to be Dean at the University of Kentucky, COM 915, the cornerstone of network analysis instruction in the graduate program, has only been taught once (spring semester of 2000 by Susskind who flew in weekly from Cornell). Dearing left M.S.U. in 2002 and eventually found a new academic home at Ohio University. No current M.S.U. Department of Communication faculty member teaches network analysis.

\section{Implications and Conclusions}

While we have intermittently looked at our small intellectual world in terms of larger themes and issues, the literature on network analysis and innovation diffusion (e.g., Rogers, 1987) suggests three general areas from which implications can be drawn of this history of 
network analysis at Michigan State University: (a) the problem of development and diffusion of computer software for network analysis, (b) continuing unresolved methodological issues, and (c) the need for better theoretical and conceptual frameworks.

\section{Computer Software}

In historical perspective, development of software programs for the analysis of network data has been largely the province of computer "nerds" who have not placed high priority on developing user-friendly software. Unfortunately, there has not been adequate professional reward for the time investment necessary for individual social scientists to write new, more userfriendly programs. Alternately, despite the development of a hegemonic software package, UCINET, network analysts are not quite in the same position as are statistical analysts in the social sciences, where researchers rely on the companies that sell SPSS and SAS to develop software, market it to users (paying attention to factors which enhance marketability such as ease of learning and use), correct bugs" and diffuse new applications. Happily, recent software developments and associated publications are moving the field to a more mature state with fullfeatured analysis packages. While large corporate interest in developing network analysis software (a la SPSS and SAS) has yet to be seen, the last 10 years have seen an increasing level of commercial interest. (For programs see: http://www.insna.org/ INSNA/soft_inf.html)

While NEGOPY was a groundbreaking software program in the early $1970 \mathrm{~s},{ }^{12}$ most of the M.S.U. graduate students trained before the 1990s were slow to try other programs, especially UCINET and STRUCTURE which were gaining traction in sociology and management science. This limited the acceptance of their work in the broader academic community. It came about partly because some of the 1970s M.S.U. clique maintained strong ties 
with each other and developed almost a group-think approach to external threats to Negopy, denying problems (e.g., Uzzi, 1997). As a result they did not feel the need to spend the extraordinary effort necessary to learn one of the competing software programs that eventually enjoyed wider legitimacy and use in the social sciences. Those in communication who have been most successful have seen structural holes within the discipline and between the communication discipline and others, and have moved to fill them in their own work. (Most interesting in this regard is the clique of Scott Poole, Bob McPhee, and Dave Seibold — all graduate students at M.S.U. when Negopy was pre-eminent — who adopted broader intellectual traditions and never became narrowly identified with a method and a tool.) But this approach comes with a price for graduate students already fully immersed in learning a broad range of statistical techniques: Learning more than one difficult network analysis program is viewed as prohibitive.

\section{Methodological Issues}

The second, and perhaps still insurmountable, problem relates to data collection both in terms of reliability of technique and richness in the characterization of relationships. At the operational level network analysis has struggled to develop truly rich descriptions of relationships between actors.

One set of problems relates to a demand for a census of network members for traditional network analysis. This is impractical in most organizational contexts. Recently, human subjects review committees have begun to raise fundamental objections to collecting network data based on a census of respondents who are asked to report on their behavior involving others. Also, because of its focus on relationships, network analysis does not mesh well with traditional 
statistical analytic frames, such as analysis of variance. This is especially problematic for the discipline of communication, which at its root assumes dependence of actors.

Network analysis using self-report data has been heavily criticized, primarily on the basis of the research stream of Bernard and Killworth (1977) and their colleagues (cf. Richards, 1985). The field of communication does not reward fundamental methodological work in the development of instruments and tools (e.g., questionnaires) for accomplishing its work. As a result, while we have developed convenient rationales for why we use self-reports, the practice of how we do this has not improved in a quarter of a century. Who will do the methodological dirty work, especially when it does not relate to career advancement? Johnson estimates that he has spent close to $50 \%$ of his research time on network analysis during his career, and only onesixth of his refereed publications relate to it. It is likely that many have noted this "cost/benefit ratio" and rationally moved on to more rewarding endeavors (particularly graduate students contemplating their critical first placement or new faculty earning tenure). Within communication in the last decade, only Corman has shown real interest in methods problems and he is a third-generation M.S.U. person (see Corman, 1990; Corman \& Bradford, 1993; Corman $\&$ Scott, 1994). Communication network analysts have not been a very good self-organizing system. Rather, we have mostly wanted to be chiefs who typically could not generate enough interest in our work to hire specialists to tackle our less glamorous problems. Revealingly, Monge and Contractor's (2001) review contains no references to these fundamental problems, but rather focuses exclusively on ideas. 


\section{Theoretical/conceptual Issues}

The third traditional problem with network analysis, which fortunately has been dramatically addressed over the last decade, is the lack of a theoretic/conceptual frame for network research. Monge and Contractor $(2001,2003)$ discuss a wide range of other theories that have been applied to network analysis (interestingly in their 2001 paper they omit systems research, which provided the conceptual foundation for work at M.S.U. in the early years). Concepts emerging from a broader network tradition - networking, six-degrees of separation, Kevin Bacon web-sites and so on-are now part of our popular culture. The Academy of Management in 2002 had a network theme for its annual convention and issued calls for network theme issues of all of its journals. Notions of connection are embedded in research about the Internet and a host of other sciences. Sadly, none of these ideas originated in communication: They are all derivative of other disciplines. So, even though we have spent considerable time working at a conceptual level, communication network analysts have yet to generate fundamental ideas that have captured the attention of the world outside of communication. 


\section{Notes}

[1] The sociometric question was originally "only a small part" of the study (Poll, Stern, \& Zipperstein, n.d.). In Weiss' view, Jacobson and Seashore had extensive socio-metric data and a conceptual frame for thinking about it but had no idea how to analyze it. Weiss needed an algorithm. He developed one that identified members of work cliques (individuals who had frequent work-related contact, primarily with each other) and two lists of individuals with contacts among those cliques: "liaison persons" (articulation points) who had contact with members of two or more separate cliques and "contacts between groups" (bridges) who were members of a clique but also had contact with a member of one other group (Weiss, 1956). Weiss analyzed the socio-metric data for his M.A. thesis, supervised by Ron Lippett. He integrated the socio-metric data with other variables for his Ph.D. dissertation, supervised by Theodore Newcomb with Robert Kahn, Daniel Katz, and David Aberly as his committee. Although Frank Harary was "a colleague down the hall," he and Weiss briefly discussed the project only once because Harary expressed "little interest in the problem" (R. S. Weiss, personal communication, January 11, 2001). Later Harary and Ian Ross published a paper on the method for identifying liaison persons (Ross \& Harary, 1955), and Ross developed a computer program for part of the process (Weiss, 1956). Weiss, University of Massachusetts Professor Emeritus of Sociology and Senior Fellow in the Gerontology Institute since 1973, has not conducted a network analysis since finishing the O.N.R. project.

[2] The M.S.U. Department of Communication was established in 1958 within the College of Communication Arts with the mission of merging the intellectual and research traditions of mass communication studies and inter-personal communication studies (separate and 
sometimes competitive departments at most major universities at that time-including M.S.U.). The department was an innovation in communication education and researchthe first purely "communication" department in the world (Rogers, 1994)—becoming what Rogers (2001, p. 234) termed "a seed institution ... an organization that plays a dominant role in the new scholarly field by shaping intellectual directions for theory and research.”

[3] Unable to meet with the committee because of his international research travel schedule, Rogers penned this note to Schwartz: "Looks like a fine dissertation in here someplace. I can't quite get my mind around the liaison-non-liaison difference. Guess we need to talk." Fourteen years later, Rogers co-authored the first text on communication network analysis (Rogers \& Kincaid, 1981).

[4] Also slowing publication, Schwartz discovered a copying error (endemic to manual network analysis) that when corrected yielded an additional liaison person. All of the statistical analyses were re-run to verify that none of the original study conclusions were incorrect: none were. Another factor affecting publication was concern about using inferential statistics on what was an "empirical case study;" i.e., the network data was a census from a population rather than a random sample (Morrison \& Hankel, 1969). Eventually Schwartz developed a rationale for using inferential statistics as a pattern detection method within a population, rather than as a test of representativeness (cf. Gold, 1969). This issue is very much alive today (see Monge \& Contractor, 2003).

[5] Farace had a separate team on inter-personal relationships and relational control that was very important to communication as a discipline in the late 1970s and early 1980s. The team included Mac Parks who became most influential in extending network ideas into 
interpersonal relationship research in the 1980s and early 1990s. His research examined friendships, romantic relationships, family relations, inter-cultural relations, and business relationships.

[6] It was at U.W.M. that Johnson saw how the world outside communication viewed M.S.U. and its decade-long focus on network analysis. Starbuck, then in the business school at U.W.M., along with Nystrom, editors of the Handbook of Organizational Design, asked Johnson to look at Tichy’s overview chapter on network analysis (Tichy, 1981). In spite of the fact M.S.U. scholars had done considerable empirical work and had a computer program of their own - and the efforts of those at business schools at this point were amazingly primitive-M.S.U. was brushed aside as an anomalous footnote in the larger path of academic progress.

[7] Fred Jablin received his Ph.D. in the Purdue climate/human resource/supervisorsubordinate organizational communication program that was the major competitor to M.S.U. at the time. Many communication scholars then believed that organizational communication was encompassed by these two traditions. Jablin was commissioned to do a chapter for Communication Yearbook (Jablin, 1980) synthesizing the two seemingly disparate positions of Purdue and M.S.U. Johnson provided much assistance in the network analysis portion because Jablin was relatively unfamiliar with it.

[8] While Burt is not an M.S.U. Ph.D., he has a "second generation" connection: He studied with Nan Lin in sociology at SUNY-Albany. Lin earned his Ph.D. in communication at M.S.U. under Everett Rogers.

[9] The CISRC grant was held by Al Marcus at the AMC Cancer Research Center in Denver. Johnson had a large sub-contract to do the network analyses. 
[10] It should be noted, however, that Torn Kiyomiya's dissertation built on a stream of Johnson's research begun in the 1990s, relating the role of context in developing communication structures through the notion of framing (Johnson, 1997b), which is closely related to the role of context in information seeking (Johnson, 2003). However, and appropriate to this story, he couldn't include a full network analysis in his dissertation because of a very low response rate for the network portion of his study. As a result, the last potential network analysis dissertation at M.S.U. (Kiyomiya graduated after Susskind) ran into some of the very same problems that had stymied research in this area for a quarter of a century.

[11] Susskind will not be alone at Cornell. The Department of Communication recently added two organizational communication scholars: Poppy McLeod (Ph.D., Harvard University) and Connie Yuan, a Ph.D. student of Peter Monge at the University of Southern California. Schwartz is still available for consultation. In 2004, three communication doctoral students were active network researchers. Michael Stefanone (2001, 2004) learned network analysis from Susskind and Krikorian. Peggy Odom completed her Masters' thesis under the supervision of Schwartz before he retired and now works with Geri Gay, Director of the Cornell Human-Computer Interaction Laboratory, and with Susskind (Susskind \& Odom, 2004). Devan Rosen studied with George Barnett at SUNY-Buffalo and entered the Cornell doctoral program in Communication in 2001 to study network analysis with Krikorian. Rosen continues to study network formation and evolution using Flock Theory under the direction of Susskind and Gay.

[12] In recent years Richards and his colleagues (Richards \& Seary, 2000) have developed FATCAT and MultiNet, new software that addresses some of the weaknesses of Negopy 
and is easier to learn and use. Released in 1988, FATCAT is for categorical analysis of multivariate multiplex communication network data. It can be applied to egocentric data, includes content, purpose, and other attributes of the relationships between people and produces graphic representations of the results. MultiNet, released in 1994 with updates through June 2004, extends FATCAT's functions to include univariate descriptive statistics plus cross tabulation, analysis of variance, regression and correlation, four types of eigen analysis, $p^{*}$, and other analyses. It also performs continuous and discrete transformations, and does linear, log, power, z, and several other types of transforms. Four types of eigen analysis are included. It can use census or sampled network data. 


\section{References}

Barabasi, A. L. (2003). Linked: How everything is connected to everything else and what it means for business, science, and everyday life. New York: Plume.

Bernard, H. R., \& Killworth, P. D. (1977). Informant accuracy in social network data: II. Human Communication Research, 4, 3-18

Biggart, N. W., \& Delbridge, R. (2004). Systems of exchange. Academy of Management Review, $29,28-49$.

Buchanan, M. (2002). Nexus: Small worlds and the groundbreaking science of networks. New York: W. W. Norton.

Burt, R. S. (1992). Structural holes: The social structure of competition. Cambridge, MA: Harvard University Press.

Burt, R. S. (2000). The network structure of social capital. Research in Organizational Behavior, 22, 345-423.

Chang, H. J., \& Johnson, J. D. (2001). Communication networks as predictors of organizational members' media choices. Western Journal of Communication, 65, 349-369.

Coleman, J. (1988). Social capital in the creation of human capital. American Journal of Sociology 94 S95-S120.

Corman, S. R. (1990). A model of perceived communication in collective networks. Human Communication Research, 16, 582-602.

Corman, S. R., \& Bradford, L. B. (1993). Situational effects on the accuracy of self-reported organizational communication behavior. Communication Research, 20, 822-840.

Corman, S. R,, \& Scott, C. R. (1994). Perceived networks, activity foci, and observable communication in social collectives. Communication Theory, 4, 171-190. 
Ethington, C. T, Johnson, J. D, Marshall, A., Meyer, M, \& Chang, H. J. (1996, May). Gender ratios in organizations: A comparative study of two organizations. Paper presented at the meeting of the International Communication Association, Chicago.

Farace, R. V., \& Johnson, J. D. (1974, May). Comparative analysis of human communication networks in selected formal organizations. Paper presented at the meeting of the International Communication Association, New Orleans, LA.

Farace, R. V., \& MacDonald, D. (1974). New directions in the study of organizational communication. Personnel Psychology, 27, 1-15.

Farace, R. V., Monge, P. R., \& Russell, H. M. (1977). Communicating and organizing. Reading, MA: Addison-Wesley.

Finlay, W., \& Coverdill, J. E. (2000). Risk, opportunism, and structural holes: How headhunters manage clients and earn fees. Work and Occupation, 27, 377-405.

Gold, D. (1969). Statistical tests and substantive significance. The American Sociologist, 4, 4241.

Hartman, R. L, \& Johnson, J. D. (1989). Social contagion and multiplexity: Communication networks as predictors of commitment and role ambiguity. Human Communication Research 15, 523-548.

Hartman, R. L., \& Johnson, J. D. (1990). Formal and informal group communication structures: An examination of their relationship to role ambiguity. Social Networks, 12, 1-24.

Ibarra, H. (1993). Network centrality, power, and innovation involvement: Determinants of technical and administrative roles. Academy of Management Journal, 36, 471-501.

Ibarra, H. (1995). Race, opportunity, and diversity of social circles in managerial networks. Academy of Management Journal, 38, 673-703. 
Jablin, F. M. (1980). Organizational communication theory and research: An overview of communication climate and network research. In D. Nimmo (Ed.), Communication yearbook (pp. 327-348). New Brunswick, NJ: Transaction Books.

Jacobson, E, \& Seashore, S. E. (1951). Communication practices in complex organizations. Journal of Social Issues, 7, 28-40.

Johnson, J. D. (1982). A model of social interaction: Tests in three situations. Central States Speech Journal, 33, 281-298.

Johnson, J. D. (1984). A model of social interaction: Phase III: Tests in varying media situations. Communication Monographs, 51, 168-184.

Johnson, J. D. (1985). A model of social interaction: Phase II: Further tests in radio and television situations. Central States Speech Journal, 36, 62-71.

Johnson, J. D. (1987). Multivariate communication networks. Central States Speech Journal 38 210-222.

Johnson, J. D. (1993). Organizational communication structure. Norwood, NJ: Ablex Publishing Corp.

Johnson, J. D. (1996). Information seeking: An organizational dilemma. Westport, CT: Quorum Books.

Johnson, J. D. (1997a). Cancer-related information seeking. Cresskill, NJ: Hampton Press.

Johnson, J. D. (1997b). A framework for interaction (FINT) scale: Extensions and refinement in an industrial setting. Communication Studies, 48, 127-141.

Johnson, J. D. (2003). On contexts of information seeking. Information Processing and Management 39, 735-760. 
Johnson, J. D. (2004). The emergence, maintenance and dissolution of structural hole brokerage within consortia. Communication Theory, 14, 212-236.

Johnson, J. D., \& Chang, H. J. (2000). Internal and external communication, boundary spanning, innovation adoption: An over-time comparison of three explanations of internal and external innovation communication in new organization form. Journal of Business Communication, 37, 238-263.

Johnson, J. D., LaFrance, B. H., Meyer, M., Speyer, J. B., \& Cox, D. (1998). The impact of formalization, role conflict, role ambiguity, and communication quality on perceived organizational innovativeness in the Cancer Information Service. Evaluation and the Health Professions, 21, 27-52.

Johnson, J. D,, Meyer, M., Berkowitz, J., Ethington, C., 8t Miller, V. (1997). Testing two contrasting models of innovativeness in a contractual network. Human Communication Research, 24, 20-348.

Johnson, J. D., Meyer, M., Berkowitz, J., Ethington, C., Miller, V., Stengle, W., \& Steverson, D. (1996). The role of a conference in integrating a contractual network of health services organizations. Journal of Business Communication, 33, 231-256.

Johnson, J. D., Meyer, M., Woodworth, M., Ethington, C., 8t Stengle, W. (1998). Information technologies within the Cancer Information Service: Factors related to innovation adoption. Preventive Medicine, 27, S71-S83.

Katz, D., Kahn, R. L., \& Adams, J. S. (Eds.). (1980). The study of organizations. San Francisco: Jossey-Bass.

Krackhardt, D., \& Porter, L.W. (1986). The snowball effect: Turnover embedded in communication networks. Journal of Applied Psychology, 71, 50-55. 
Labianca, G., Brass, D. J., \& Gray, B. (1998). Social networks and perceptions of intergroup conflict: The role of negative relationships and third parties. Academy of Management Journal, 41, 55-67.

MacDonald, D. (1970). Communication roles and communication context in a bureaucratic setting. Unpublished doctoral dissertation, Michigan State University, East Lansing.

Mayhew, B. H. (1980). Structuralism versus individualism: Part 1. Shadowboxing in the dark. Social Forces, 59, 335-374.

Meyer, M., Johnson, J. D., \& Ethington, C. (1997). Contrasting attributes of preventive health innovations. Journal of Communication, 47, 112-131.

Meyer, M. E. (1996). The effects of weak ties on perceived organizational innovativeness and innovation characteristics. Unpublished doctoral dissertation, Department of Communication, Michigan State University, East Lansing.

Monge, P. R., \& Contractor, N. S. (2001). Emergence of communication networks. In F. M. Jablin \& L. L. Putnam (Eds.), The new handbook of organizational communication (pp. 440-502). Thousand Oaks, CA: Sage.

Monge, P. R., \& Contractor, N. S. (2003). Theories of communication networks. New York: Oxford University Press.

Morrison, D. E., \& Henkel, R. E. (1969). Significance tests reconsidered. The American Sociologist, 4, 131-140.

Newman, M. E. J. (2003). The structure and function of complex networks. SIAM Review, 45 (2), 167-256. Retrieved July 01, 2004, from http://epubs.siam.org/sambin/dbq/article/42480 
Pescosolido, B. A., \& Rubin, B. A. (2000). The web of group affiliations revisited: Social life, postmodernism, and sociology. American Sociological Review, 65, 52-76.

Porter, L., \& Roberts, K. (Eds.). (1977). Communication in organizations. Harmondsworth, UK: Penguin Books.

Poll, O. C., Stern, H., \& Zipperstein, D. (n.d.). Methodological report of sociometric study of personnel in a government agency (Mimeo. Rep.). Ann Arbor, MI: University of Michigan Institute for Social Research.

Putnam, R. (2000). Bowling alone: The collapse and revival of American community. New York: Simon \& Schuster.

Reynolds, E. V., \& Johnson, J. D. (1982). Liaison emergence: Relating theoretical perspectives. Academy of Management Review, 7, 551-559.

Rice, R. E, \& Richards, W. D. (1985). An overview of network analysis methods and programs. In R. Dervm \& M. J. Voight (Eds.), Progress in communication sciences (pp. 105-165). Norwood, NJ: Ablex.

Richards, W. D. (1985). Data, models and assumptions in network analysis. In R. McPhee \& P. Tompkins (Eds.), Sage annual reviews of communication research: Vol. 13. Organizational communication: Traditional themes and new directions (pp. 109-128). Beverly Hills, CA: Sage.

Richards, W. D., \& Barnett, G. (Eds.). (1993). Progress in communication sciences: Advances in communication network analysis. Norwood, NJ: Ablex.

Richards, W. D,, \& Rice, R. E. (1981). The Negopy network analysis program. Social Networks, $3,215-223$. 
Richards, W. D., \& Seary, A. J. (2000). Eigen analysis of networks. Journal of Social Structure, $I$ (2). Retrieved September 17, 2005, from http://www.cmu.edu/joss/ and http://www.cmu.edu/joss/ content/articles/volumel/RichardsSeary.html

Rogers, E. M. (1962). The diffusion of innovations. New York: Free Press.

Rogers, E. M. (1987). Progress, problems, and prospects for network research: Investigating relationships in the age of electronic communication technologies. Social Networks, 9 , 285-310.

Rogers, E. M. (1994). A history of communication study: A biographical approach. New York: Free Press.

Rogers, E. M. (2001). The Department of Communication at Michigan State University as a seed institution for communication study. Communication Studies, 52(3), 234-248.

Rogers, E. M., \& Agarwala-Rogers, R. (1976). Communication in organizations. New York: Free Press.

Rogers, E. M,, \& Kincaid, L. (1981). Communication networks: Toward a new paradigm for research. New York: Free Press.

Ross, I. C., \& Harary, F. (1955). Identification of the liaison persons of an organization using the structure matrix. Management Science, 1, 251-258.

Schwartz, D. F. (1968). Liaison communication roles in a formal organization. Unpublished doctoral dissertation, Michigan State University, East Lansing. (UMI No. 69-11, 162). (Reprinted as Communimetrics Report \#1, Department of Communication, Division of Social and Behavioral Sciences, North Dakota State University, Fargo, September 1968)

Schwartz, D. F. (1969, April). Liaison roles in the communication structure of a formal organization: A pilot study. Paper presented at the meeting of the International 
Communication Association, Cleveland, OH. (ERIC Document Reproduction Service No. ED098638)

Schwartz, D. F., \& Jacobson, E. (1977). Organizational communication network analysis: The liaison communication role. Organizational Behavior and Human Performance, 18, 158174.

Seary, A. J, \& Richards, W. D. (2003). Spectral methods for analyzing and visualizing networks: An introduction. In R. Breiger, K. Carley \& P. Pattison (Eds.) Dynamic social network modeling and analysis (pp. 209-228). Washington, DC: National Academy Press.

Seary, A. J,, Richards, W. D, McKeown-Eyssen, G,, \& Baines, C. (2005). Networks of symptoms and exposures. Structure and Dynamics, 1 . http://repositories.cdlib.org/imbs/socdyn/sdeas

Seibert, S. E, Kraimer, M. L, \& Liden, R. C. (2001). A social capital theory of career success. Academy of Management Journal, 44, 219-237.

Shah, P. P. (1998). Who are employees' social referents? Using a network perspective to determine referent others. Academy of Management Journal, 41, 249-268.

Shah, P. P. (2000). Network deconstruction: The structural implications of downsizing. Academy of Management Journal, 43, 101-112.

Stefanone, M. A. (2001). The social network's influence on computer-mediated communication. Unpublished master's thesis, Department of Communication, Cornell University, Ithaca, NY.

Stefanone, M. A. (2004). Locus of control, instrumental action, and the pursuit of social capital. Unpublished doctoral dissertation, Department of Communication, Cornell University Ithaca, NY. 
Susskind, A. M. (1996). The impact of an organizational downsizing effort on survivors' communication network relationships and attitudes. Unpublished doctoral dissertation, Department of Communication, Michigan State University, East Lansing.

Susskind, A. M. (2005). Downsizing survivors' communication networks and reactions: An examination of information adequacy and turnover intentions. Manuscript submitted for publication.

Susskind, A. M., Miller, V. D., \& Johnson, J. D. (1998). Downsizing and structural holes: Their impact on layoff survivors' perceptions of organizational chaos and openness to change. Communication Research, 25(1), 30-65.

Susskind, A. M., \& Odom, P. (2004, May). Do liaisons have a role in teams? Examining the performance implications of liaisons in inter-organizational networks. Paper presented at the meeting of the International Communication Association, New Orleans, LA.

Taylor, M., \& Doerfel, M. L. (2003). Building interorganizational relationships that build nations. Human Communication Research, 29, 153-181.

Tichy, N. M. (1981). Networks in organizations. In P. Nystrom \& W. Starbuck (Eds.), Handbook of organizational design (Vol. 2, pp. 203-224). New York: Oxford University Press.

Uzzi, B. (1997). Social structure and competition in interfirm networks: The paradox of embeddedness. Administrative Science Quarterly, 42, 35-67.

Weiss, R. S. (1956). Processes of organization. Ann Arbor, MI: Institute for Social Research, University of Michigan.

Weiss, R. S., \& Jacobson, E. (1955). A method for the analysis of the structure of complex organizations. American Sociological Review, 20, 661-668. 